\title{
Methodological adaptation for nematodes extration in forest soils of the southern Mata Atlântica
}

\author{
Thomas Moser(1) and Silja Frankenbach ${ }^{(1)}$ \\ (1)ECT Oekotoxikologie GmbH, Böttgerstrasse 2-14, D-65439 Flörsheim, Germany. E-mail: th-moser@ect.de
}

\begin{abstract}
The objective of this work was to clarify whether the method to extract nematodes from European soils is suitable for forest soils and litter in the eastern of Paraná state, Brazil, and whether nematode abundance differs between sites with different ecosystems and levels of human interference. The study sites were situated in the coastal area of the Serra do Mar, near the town of Antonina, in Eastern Paraná, Brazil. Cobb's sieving and decanting method was more appropriate than ISO method, since extraction efficiency was higher and intrasample variability was significantly lower. In order to achieve an extraction efficiency higher than $90 \%$, Cobb's method was modified. For the extraction of nematodes from litter, the Baermann funnel, with an extraction time of 48 hours, yielded an extraction efficiency higher than $90 \%$. Nematode abundance in litter was higher than in soil. The mean number of individuals extracted from the litter increased with the age stage of the forest sites sampled, and there was no difference in the number of individuals in the soil of the four forest sites. Mean nematode abundance in soil in banana plantations was about twice as high compared to the banana-palmito mixed stands and to the forest sites.
\end{abstract}

Index terms: agroforestry system, bioindicator, extraction method, Nematoda.

\section{Adaptação metodológica para extração de nematódeos em solos florestais da Mata Atlântica do Sul do Brasil}

\begin{abstract}
Resumo - O objetivo deste trabalho foi verificar se o método de extração de nematódeos, aplicado em solos europeus, é apropriado para solos de florestas e para serapilheira do leste do Estado do Paraná, e se a abundância de nematódeos difere entre os diversos ecossistemas e os níveis de interferência humana. Os locais estudados situam-se na área costeira da Serra do Mar, próximo do Município de Antonina, no Leste do Paraná. $\mathrm{O}$ método Cobb de peneiramento e decantação foi considerado mais apropriado do que o método ISO, pois a eficiência da extração foi maior, e a variabilidade intra-amostral foi significativamente menor. Para conseguir uma eficiência de extração acima de $90 \%$, o método Cobb foi modificado. Para a extração de nematódeos da serapilheira, o funil de Baermann, com tempo de extração de 48 horas, rendeu eficiência de extração acima de $90 \%$. A abundância de nematódeos em serapilheira foi maior do que no solo. O número médio de indivíduos extraídos da serapilheira aumentou com a idade da floresta na área amostrada, e não houve diferença quanto ao número de indivíduos nos solos dos quatro sítios de floresta. A abundância média no solo dos plantios de banana foi quase o dobro da observada em sítios de plantio misto de banana com palmito e em sítios de floresta.
\end{abstract}

Termos para indexação: sistema agroflorestal, indicador biológico, método de extração, Nematoda.

\section{Introduction}

Mata Atlântica (Brazilian Atlantic Forest) is among the most diverse and most threatened ecosystems of the world. Its forests originally covered about 1.3 million $\mathrm{km}^{2}$, corresponding to $15 \%$ of the land surface of Brazil, extending for more than 3,000 km along the eastern Brazilian coast, between $6^{\circ} \mathrm{S}$ and $30^{\circ} \mathrm{S}$ (Fundação SOS Mata-Atlântica, 1993). The region has been largely impacted by colonization, which resulted in extensive deforestation, conversion into farmland and urbanization. Consequently, forest has been reduced to about $7 \%$ of the original area, or less than $100,000 \mathrm{~km}^{2}$ (Schäffer \& Prochnow, 2002). In the remaining forested area, one of the largest remnants is found at the coast of Paraná. It encloses a mosaic of environments at elevations ranging from sea level to more than 1,500 $\mathrm{m}$ a.s.1. As a consequence of the geomorphologic and climatic variations, the dense ombrophilous forest (Veloso et al., 1991) is divided in 
four subformations (lowland, alluvial, submountain and mountain forest), each presenting distinct floral and structural characteristics (Instituto Brasileiro de Geografia e Estatística, 1992). In addition, small agroforestry sites are scattered in the same area.

Nematoda are amongst the most numerous soil animals, also showing a high diversity. However, due to their small size and complex extraction from soils, they are relatively rarely studied. In forest soils of tropical regions in general, and of South America in particular, almost nothing is known about free-living nematodes. Most taxonomic effort have been addressed towards important plant parasites (Huang \& Cares, 2006).

The main objectives of the present study were to clarify whether the method to extract nematodes from European soils is suitable for forest soils and litter of eastern Paraná, and to identify whether nematode abundance differs between sample sites with different ecosystems and levels of human interference.

\section{Materials and Methods}

Abundance and distribution of nematodes were studied in four forest sites of different ages and six agroforestry sites (three banana monocultures and three mixed banana-palmito plantations), located in Brazilian Mata Atlântica, in 2008. The investigation was part of the German-Brazilian cooperative project Solobioma (Project Solobioma, 2009), which aims to assess the ecosystem quality of secondary forests in this region of eastern Paraná and their potential to conserve biodiversity and related ecosystem services.

The study sites were located in the coastal plain area of the state of Paraná, in the municipalities of Antonina and Guaraqueçaba. Soils were characterized by low $\mathrm{pHCaCl}_{2}$ (3.5-4.3), variable $\mathrm{C} / \mathrm{N}$-ratios (15-40), and medium organic matter contents $(2-5 \%)$, in the upper
$20 \mathrm{~cm}$ soil layer (Ferretti \& Britez, 2006). Details of the site characteristics, including exact UTM coordinates are shown in Table 1, and further information on the sample sites can be found in Römbke et al. (2009).

The climate of the coastal region of Paraná can be described as mesothermic subtropical humid, corresponding to the Cfa type, according to Köppen's classification (Schröder, 2000; Strahler \& Strahler, 2005). Mean annual temperature is above $18^{\circ} \mathrm{C}$, and monthly precipitation over $60 \mathrm{~mm}$. Frost rarely occurs in areas from sea level up to $700 \mathrm{~m}$ a.s.l. (Instituto Paranaense de Desenvolvimento Econômico e Social, 2001). Annual rainfall in the region varies between 2,000 and 3,000 mm (Roderjan \& Kunyoshi, 1988) and has seasonality. Lower rainfall occurs from the end of autumn to winter (April to August), and higher rainfall during the warmer Brazilian summer (September to March) (Instituto Paranaense de Desenvolvimento Econômico e Social, 2001).

Nematodes were sampled in four forest age stages (initial herbaceous, young arboreal, medium stage secondary forests, and old-growth forest, one site each, on sites no. $32,35,38$ and 41 , in Table 1) on Cambisols; as well as in two agroforestry systems (banana and banana-palmito, three sites each, no. 46-51, in Table 1) on Gleysols. The forest stages represent phases of the natural regeneration process, covering patches of forests differing in age ( 3 to $>80$ years) and thus anthropogenic influence. The forest regeneration sites were in the Itaqui reserve owned to and administrated by the regional NGO Society for Wildlife Research and Environmental Education (SPVS). The two agroforestry systems were located just outside, at a place called Rio Pequeno, about $20 \mathrm{~km}$ north of Antonina. Both were plantations, grown with banana or a mixture of banana and palmito (Euterpe edulis) plants.

Table 1. Characteristics of the 10 study sites in eastern Paraná, Brazil. Site numbers correspond to the Solobioma project sample sites (Römbke et al., 2009).

\begin{tabular}{|c|c|c|c|c|c|c|c|c|c|}
\hline $\begin{array}{l}\text { Site } \\
\text { number }\end{array}$ & County & $\begin{array}{c}\text { General } \\
\text { sampling area }\end{array}$ & Ecosystem & Soil type & $\begin{array}{c}\text { Succession } \\
\text { stage }\end{array}$ & $\begin{array}{c}\text { Age in } \\
2003 \text { (years) }\end{array}$ & $\begin{array}{l}\text { Altitude } \\
\text { (m a.s.1.) }\end{array}$ & $\begin{array}{r}\text { UTM coor } \\
\text { easting }\end{array}$ & $\begin{array}{l}\text { s (SAD69) } \\
\text { northing }\end{array}$ \\
\hline 32 & Guaraqueçaba & Itaqui & Forest & Cambisol & Herbaceous & $3-5$ & 46 & 749433 & 7205484 \\
\hline 35 & Guaraqueçaba & Itaqui & Forest & Cambisol & Arboreal & $10-15$ & 36 & 749752 & 7205013 \\
\hline 38 & Guaraqueçaba & Itaqui & Forest & Cambisol & Medium & $35-50$ & 27 & 751327 & 7205532 \\
\hline 41 & Guaraqueçaba & Itaqui & Forest & Cambisol & Old & $>80$ & 31 & 750950 & 7204080 \\
\hline 46 & Antonina & Rio Pequeno & Agroforest monoculture & Gleysol & - & - & 40 & 727013 & 7206145 \\
\hline 47 & Antonina & Rio Pequeno & Agroforest monoculture & Gleysol & - & - & 15 & 728835 & 7202908 \\
\hline 48 & Antonina & Rio Pequeno & Agroforest monoculture & Gleysol & - & - & 25 & 727662 & 7203747 \\
\hline 49 & Antonina & Rio Pequeno & Agroforest mixed & Gleysol & - & - & 16 & 731179 & 7202942 \\
\hline 50 & Antonina & Rio Pequeno & Agroforest mixed & Gleysol & - & - & 12 & 730852 & 7202331 \\
\hline 51 & Antonina & Rio Pequeno & Agroforest mixed & Gleysol & - & - & 37 & 727032 & 7206176 \\
\hline
\end{tabular}


At each site, five plots were established, and ten samples (subsequently mixed and reduced to five composite samples) were taken with a soil corer (2.5-cm diameter; $10-\mathrm{cm}$ depth). Additionally, at the forest sites, litter samples were taken. Nematodes were extracted from soil through the modified sieving and decanting method of Cobb (Cobb, 1918; S'Jacob \& Van Bezooijen, 1984; Southey, 1986), and the ISO method (International Organization for Standardization, 2005). For the litter samples, Baermann funnel extraction (Baermann, 1917) was used. Since these methods were developed for temperate soils, additional experiments were conducted: a comparison of the extraction efficiency of the Cobb and ISO method; a comparison of intra-sample variability of these methods; and a comparison between different extraction times for Baermann's method.

For the extraction of free-living nematodes from soil, according to Cobb's modified decanting and sieving method, each composite sample was thoroughly mixed, and a subsample of $50 \mathrm{~g}$ fresh weight was steeped in $400 \mathrm{~mL}$ tap water for approximately $15 \mathrm{~min}$. Then, soil and water were stirred for $60 \mathrm{~s}$; and after $15 \mathrm{~s}$ of sedimentation, the supernatant was carefully decanted in a collecting plastic bowl. This procedure was repeated twice, each time with $400 \mathrm{~mL}$ tap water. The remaining sediment was discarded, and the combined nematode suspension was poured through a cascade of several sieves with decreasing mesh sizes $(1,000,350,175,100$ and $45 \mu \mathrm{m})$. To improve cleaning, the nematode suspension was poured five times through the $45 \mu \mathrm{m}$ sieve. The nematodes on the $45 \mu \mathrm{m}$ sieve were rinsed with tap water and transferred in a separate plastic bowl. The collected supernatant of the nematode suspension was carefully decanted. The remaining nematodes were poured into an extraction sieve containing a cotton-wool filter and placed in a shallow tray filled with tap water. Within the following 24 hours, the nematodes actively moved through the cotton-wool into the tray. This nematode suspension was poured through a small $20 \mu \mathrm{m}$ sieve to separate the nematodes from the water. The nematodes were carefully rinsed from the $20 \mu \mathrm{m}$ sieve into a counting dish; thereafter they were counted.

For the extraction of free-living nematodes from soil by the ISO method, a subsample of $50 \mathrm{~g}$ fresh weight of the mixed composite sample was also taken. Plastic bowls (diameter ca. $20 \mathrm{~cm}$, height ca. $10 \mathrm{~cm}$ ) were carefully filled up with tap water until empty plastic sieves (diameter ca. $15 \mathrm{cam}$, mesh width ca. $0.5 \mathrm{~mm}$ ) were completely covered by the water. The samples were put into the sieves, and were, if necessary, carefully broken apart by hand. The bottom of the sieves did not reach the bottom of the bowls. At the end of the extraction period, after 24 hours, the sieves were removed and the soil was discarded. The water including the nematodes was slowly and carefully decanted from the bowls and poured through a small $20 \mu \mathrm{m}$ sieve to separate the nematodes from the water and the sediment. Thereafter, the nematodes were counted.

For the extraction of free-living nematodes from litter, by the Baermann funnel method, litter samples (10 g fresh weight) were carefully cut into ca. $1 \mathrm{~cm}$ seized pieces. Thereafter, each sample was wrapped in a piece of cheesecloth, forming a loose ball. Funnels (slope of the sides approximately $45^{\circ}$ ) with a piece of soft silicone rubber tubes attached to the stem, closed with a squeezer clip, were placed in a funnel stand. The funnels were filled with tap water until it reached up to $\mathrm{ca} .1 \mathrm{~cm}$ below the rim. The cheesecloth containing the sample was hanged in the funnel so that the sample was totally submerged, without touching the bottom of the funnel. After a period of 24 hours, the nematode suspension was tapped by opening the squeezer clip carefully, and the nematodes were counted at first time. After further 24 hours, the nematode suspension was tapped again and the nematodes were counted a second time.

All nematodes were counted alive, under an inverse microscope (magnification $160 \mathrm{x}$ ). The counted samples were transferred into $5 \mathrm{~mL}$ polypropylene tubes. For the taxonomical identification of the nematodes, the samples were heated up to $60^{\circ} \mathrm{C}$ and conserved in formaldehyde (4\%). Until identification, the samples were stored in a refrigerator at $4-6^{\circ} \mathrm{C}$. Identification at least to family level (trophic groups) and further data assessment as maturity index (Bongers, 1990) are to be completed.

\section{Results and Discussion}

Cobbversus ISOextraction efficiencywerecompared, and the mean number of individuals extracted from five soil samples of medium secondary forest by Cobb's method was slightly but consistently higher than those extracted by the ISO method (Table 2). However, the 
difference was not statistically significant. The coefficient of variation, as a measure of the variability between samples, did not differ between the extraction methods.

Afterwards, Cobb's method was compared to ISO's method, focusing on intra-sample variability. The coefficient of variation, for the mean number of nematodes of four subsamples of one particular soil sample of medium secondary forest, extracted by the Cobb method, was less than half as high as the one determined through the ISO method (Table 2). This difference was statistically significant (t-test; two-sided, $\mathrm{p}<0.05$ ). For both methods, it can be stated that intra-sample variability was clearly below inter-sample variability.

Since extraction efficiencywashigher, and intra-sample variability was significantly lower, Cobb's sieving and decanting method was preferable to the ISO's method, and was used for all further extractions. However, due to the small sizes (diameter of 20-35 $\mu \mathrm{m}$ ) of a great portion of the nematodes extracted from the Cambisols, the last extraction step (pouring the nematode suspension over a $20 \mu \mathrm{m}$ gauze) should be repeated at least twice to retain more than $90 \%$ of the total number.

Finally, the optimum extraction time of litter samples was determined. Nematodes of five litter samples of the medium forest site were extracted using Baermann funnels and counted after 24 hours, and again after 48 hours. On average, only $10.8 \%$ of the nematodes found in the first count ( 24 hours) were determined in the second count (48 hours). This result was confirmed in a second group of five litter samples, from the old growth forest site: the second count yielded $9.2 \%$ of the first count. Therefore, for all further extractions, a total extraction time of 48 hours with two counts after 24 and 48 hours was regarded to be sufficient to extract more than $90 \%$ of the total number of nematodes and, at the same time, to check the extraction efficiency.

Table 2. Means, standard deviations (SD) and the coefficient of variation $(\mathrm{CV})$ of nematode number (individuals $100 \mathrm{~g}^{-1}$ soil dry weight) extracted from a medium secondary forest soil by Cobb's or ISO method.

\begin{tabular}{lccc}
\hline Extraction Method & Mean & SD & CV $(\%)$ \\
\hline \multirow{3}{*}{ Same five samples } \\
Cobb & 434.3 & 260.4 & 60.0 \\
ISO & 340.0 & 182.2 & 53.6 \\
\hline \multicolumn{4}{c}{ Four subsamples of a particular sample } \\
Cobb & 710.5 & 116.8 & 16.4 \\
ISO & 362.0 & 131.5 & 36.3 \\
\hline
\end{tabular}

At the four forest sites, on average 511.2-781.3 nematodes per $100 \mathrm{~g}$ soil dry weight were found. Their abundance did not differ significantly between the four forest sites (Figure 1). In general, nematode abundance in litter was much higher than in soil. Between 7,687.5 and 29,194.0 individuals per $100 \mathrm{~g}$ litter dry weight were found (Figure 2). Their mean number in litter increased with the age stage of the forest sampled. However, in the litter of the sites with intermediate age

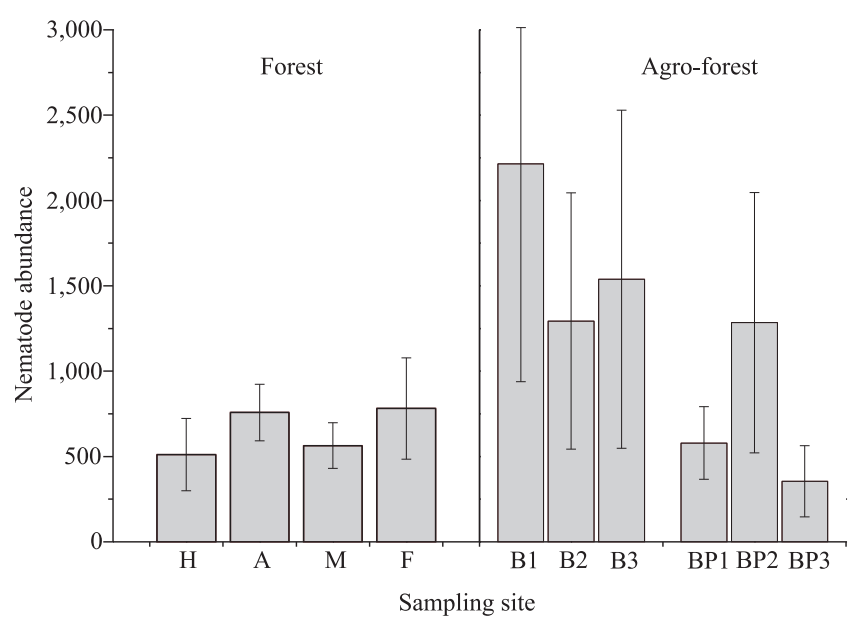

Figure 1. Nematode number in soil (individuals per $100 \mathrm{~g}$ of soil dry weight), in forest of four different age stages: $\mathrm{H}$, young; A, advanced; $\mathrm{M}$, medium secondary forests; $\mathrm{F}$, old-growth forest (one site each); and in two different agroforestry systems: B, banana; BP, banana-palmito (three sites each). Mean \pm standard deviation $(n=5)$.

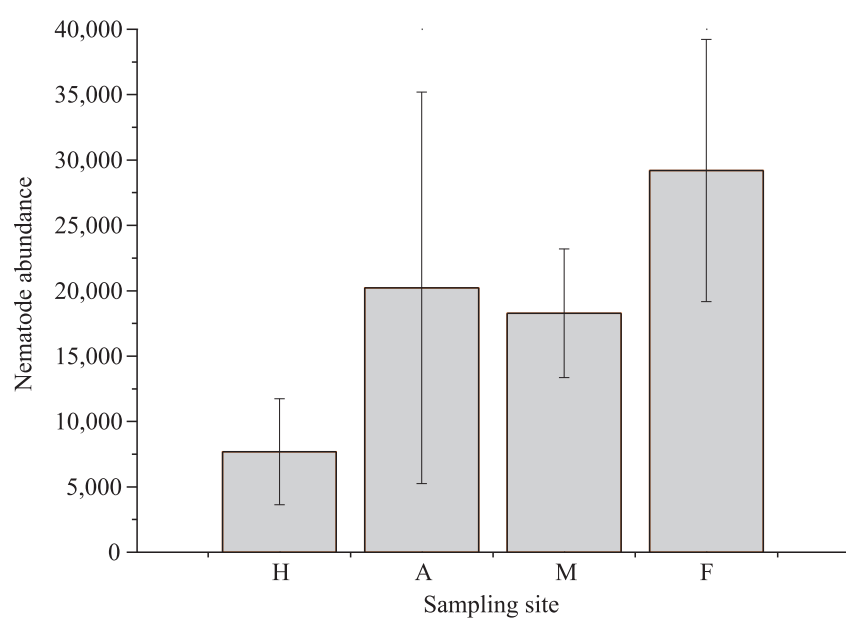

Figure 2. Nematode number in litter (individuals per $100 \mathrm{~g}$ of litter dry weight), in forests of four different age stages: $\mathrm{H}$, young; A, advanced; M, medium secondary forests; F, old-growth forest (one site each). Mean \pm standard deviation $(n=5)$. 
(advanced and medium stage), no difference was found. Nevertheless, the difference in abundance between the young and old growth forests was statistically significant (t-test; two-sided, $\mathrm{p}<0.05$ ).

The mean nematode abundance in soil, at the two different agroforestry systems, differed markedly. The abundance was more than twice as high at the banana plantations, compared to the banana-palmito mixed stands (Figure 1). However, this difference was not statistically significant, due to the high variability in nematode numbers, particularly in the three banana monoculture sites. The mean abundance determined for the banana-palmito mixed stands was similar to the ones of the four different forest sites. Litter could not be evaluated, since there was not enough material available on the agroforestry sites.

The nematode abundance, determined for the forest soils, was similar to the ones observed in literature (Peterson \& Luxton, 1982; Bloemers et al., 1997). However, sampling techniques, sampling depth and extraction methods often vary in different projects and, sometimes, account for differing results (Mulder et al., 2005). Therefore, comparisons of nematode densities between studies should be made very cautiously.

The results from the forest sites (no difference in soil, but increasing numbers in the litter with increasing age) should be verified by assessing at least further two sites of each stage. Even more importantly, the nematodes sampled so far should be identified at least to family level, in order to determine the percentage of the trophic groups. This information should be used to calculate the maturity index (Bongers, 1990), and to clarify whether their diversity at the different sites differs or not. Finally, the usefulness of nematodes for the biological classification and assessment of these soils must still be ascertained.

\section{Conclusions}

1. Cobb's modified sieving and decanting method is more appropriate than the ISO method, for the extraction of nematodes from tropic forest soils, presenting extraction efficiency higher than $90 \%$.

2. The Baermann funnel method, with an extraction time of 48 hours, yields extraction efficiency higher than $90 \%$ and is suitable for the extraction of nematodes from litter of tropical forests.
3. The mean number of nematodes extracted from soil does not differ between the four forest sites, whereas the mean number of individuals extracted from litter increases with the age stage of the forest sites sampled.

4. Mean nematode abundance in soil in banana plantations was about twice as high compared to the banana-palmito mixed stands and to the forest sites.

\section{Acknowledgements}

To the German Federal Ministry of Education and Research (BMBF Project 01LB0201) and to Conselho Nacional de Desenvolvimento Científico e Tecnológico (CNPq, Proc. 590042/2006-8), within the Brazilian-German Mata Atlântica program, for support; to the Brazilian NGO Society for Wildlife Research and Environmental Education (SPVS), for permit and support on the field work at their reserves "Reserva Natural Rio Cachoeira" and "Reserva Natural Serra do Itaqui"; to our Solobioma colleagues, for helping during our sampling campaigns, in particular to Stephan Meyer and Petra Schmidt; and to Rüdiger Schmelz, for fruitful discussions.

\section{References}

BAERMANN, G. Eine einfache Methode zur Auffindung von Ankylostomum (Nematoden) larven in Erdproben. Geneeskundig Tijdschrift voor Nederlandsch Indië, v.57, p.131-137, 1917.

BLOEMERS, G.F.; HODDA, M.; LAMBSHEAD, P.J.D.; LAWTON, J.H.; WANLESS, F.R. The effects of forest disturbance on diversity of tropical soil nematodes. Oecologia, v.111, p.575-582, 1997.

BONGERS, T. The maturity index: an ecological measure of environmental disturbance based on nematode species composition. Oecologia, v.83, p.14-19, 1990.

COBB, N.A. Estimating the nema population of the soil. [Washington]: United States Department of Agriculture, 1918. 48p. (Agricultural Technical Circular, 1).

FERRETTI, A.R.; BRITEZ, R.M. de. Ecological restoration, carbon sequestration and biodiversity conservation: the experience of the Society for Wildlife Research and Environmental Education (SPVS) in the Atlantic Rain Forest of Southern Brazil. Journal for Nature Conservation, v.14, 249-259, 2006.

FUNDAÇÃO SOS MATA ATLÂNTICA. Evolução dos remanescentes florestais e ecossistemas associados no domínio da Mata Atlântica no período 1990-1995. São Paulo: Fundação Mata Atlântica: Instituto Nacional de Pesquisas Espaciais, 1993.

HUANG, S.P.; CARES, J.E. Nematode communities in soils under different land-use systems in Brazilian Amazon and 
savannah vegetation. In: MOREIRA, F.M.S.; SIQUEIRA J.O.; BRUSSAARD, L. (Ed.). Soil biodiversity in Amazonian and other Brazilian ecosystems. Wallingford: CAB International, 2006. p.163-183.

INSTITUTO BRASILEIRO DE GEOGRAFIA E ESTATÍSTICA. Manual técnico da vegetação brasileira. Rio de Janeiro: IBGE, 1992. 92p. (IBGE. Série Manuais Técnicos em Geociências, 1).

INSTITUTO PARANAENSE DE DESENVOLVIMENTO ECONÔMICO E SOCIAL. Zoneamento da área de proteção ambiental de Guaraqueçaba. Curitiba: Ipardes, 2001. 150p.

INTERNATIONAL ORGANIZATION FOR STANDARDIZATION. ISO 23611-1: soil quality - sampling of soil invertebrates - Part 4: sampling, extraction and identification of soil-inhabiting nematodes. Geneve: ISO, 2005.

MULDER, C.; SCHOUTEN, A.J.; HUND-RINKE, K.; BREURE, A.M. The use of nematodes in ecological soil classification and assessments concepts. Ecotoxicology and Environmental Safety, v.62, p.278-289, 2005.

PETERSON, H.; LUXTON, M. A comparative analysis of soil fauna populations and their role in decomposition processes. Oikos, v.39, p.287-388, 1982.

PROJECT SOLOBIOMA. Project Solobioma [home page]. <Available at: http://www.solobioma.ufpr.br/>. Acessed on: 03 Sept. 2009.
RODERJAN, C.V.; KUNYOSHI, Y.S. Macrozoneamento florístico da área de proteção ambiental - APA - Guaraqueçaba. Curitiba: Fundação de Pesquisas Florestais do Paraná, 1988. (FUPEF. Série Técnica, 15).

RÖMBKE, J.; SCHMIDT, P.; HÖFFER, H. The earthworm fauna of regenerating forests and anthropogenic habitats in the coastal region of Paraná. Pesquisa Agropecuária Brasileira, v.44, p.1040-1049, 2009.

S'JACOB, J.J.; VAN BEZOOIJEN, J. A manual for practical work in nematology. Wageningen: Wageningen Agricultural University, 1984. 76p.

SCHÄFFER, W.B.; PROCHNOW, M. (Org.). A Mata Atlântica e você: como preservar, recuperar e se beneficiar da mais ameaçada floresta brasileira. Brasília: Associação de Preservação do Meio Ambiente do Alto Vale do Itajaí, 2002. 156p.

SCHRÖDER, P. Die Klimate der Welt: aktuelle Daten und Erläuterungen. 159p. Stuttgart: Thieme, 2000. 159p.

SOUTHEY, J.F. Laboratory methods for work with plant and soil nematodes. London: Ministry of Agriculture, 1986. 402p.

STRAHLER, A.H.; STRAHLER, A.N. Physische Geographie. Stuttgart: Eugen Ulmer, 2005. 686p.

VELOSO, H.P.; RANGEL-FILHO, A.L.; LIMA, J.C.A. Classificação da vegetação brasileira adaptada a um sistema universal. Rio de Janeiro: IBGE, 1991. 123p.

Received on September 17, 2008 and accepted on June 25, 2009 